\title{
On the Three Forms of Fruitless Love in Sons and Lovers*
}

\author{
WANG Xiao-yan \\ Changchun University, Changchun, China
}

\begin{abstract}
David Herbert Lawrence is one of the greatest English novelists of the 20th century. He is not only a turn-of-the-century social reformer, but also an artist deeply concerned with human relationships. His famouse work-Sons and Lovers (1994), describes the process of young Paul's growth with young Lawrence's personal life as the model. The present paper, first of all, gives a brief introduction of the novel. Then the three forms of unreal love in the story are what the present paper mainly explored. Firstly, the love between Paul and his mother is a distorted love between a mother and a son. Secondly, the love between Paul and Miriam is an immature love of young people. Thirdly, the love between Paul and Clara is physical and short-lived. The three forms of love are unreal and doomed to be fruitless.
\end{abstract}

Keywords: Sons and Lovers, love, Paul Morel, Gertrude Morel, Miriam Leivers, Clara Dawes

\section{Introduction}

David Herbert Lawrence is one of the pioneers in modernist fiction which emphasize the description of the characters’ psychological activities, and so has sometimes been called modern psychological fiction (LIU, 2001, p. 488). Ronald Draper, the most recent surveyor of the Lawrence canon, said, "the finest achievement of Sons and Lovers is its quickening truthfulness to actual life” (Gilbert, 1997, p. 83).

Sons and Lovers (1994) is one of the classic novels in the 20th century of world literature. It is a kind of autobiographical and modeled on the life of young Lawrence. It is set in a coal-minging district. The hero, Paul Morel, who resembles Lawrence in family situation, was born in a coal miner's family. His father, Walter Morel, is a miner, easy-gong pleasant-seeking and irresponsible. His mother, Mrs Gertrude Morel, is a refined, puritanical and strong-willed woman from the middle class, who has no satisfaction in the roughness and illiteracy of her uneducated husband. Mentally isolated, she pins her hopes on her children. After the premature death of her elder son, she invests in Paul, her younger son, all her hopes and passions. But her all-possessive affection for her son becomes a hinderance to his independent development as a man. She opposes his love for Miriam, a farmer's daughter. Meantime, Paul, feeling Miriam's love egocentric and intolerable, turns from her to Clara, a woman estranged from her husband and potentailly sensual. But fiding her passion stifling, he also left her. In the end, Mrs. Morel dies of cnacer. Paul, costing off three forms of unreal love, stands free and intends to seek for a more valid mode of life.

\footnotetext{
* Acknowledgements: This paper is a part of the results of the research programs the author participated "The Study of the Female Characters' Social Position in the Early Stage of 20th Century Foreign Literature” [2013] No. B137 and “The Cognitive Orientation Study of Chinese Foreign Language Teaching in China from Global Perspective” [2013] No. 251.

WANG Xiao-yan, associate professor, School of Foreign Languages, Changchun University.
} 
The three forms of fruitless love are what this paper want to explore.

\section{Love Between Paul and Mrs. Morel}

The central character of the novel Paul is a keen, wiry, expressive and aloof young man. From childhood on Paul is especially sensitive, artistic, and imaginative, yet he becomes extraordinarily dependent on his mother, who is a refined, highly intelligent, ambitious, and thrifty woman with an unusually strong and vivid personality. She devotes herself passionately to her sons, yet her special love also spoils her son.

We can understand the love between Mrs. Morel and Paul in this way: Paul's love to his mother is still a woman's natural love for a son. It is only that when Mrs. Morel, the proud willful woman who cannot satisfy her own ambitious nature directly, is disappointed by her brutish, hard-drinking coal-miner husband through whom she cannot indirectly reach her high goal, she turns her love to her sons who are more like herself and more like what a man in a given society is expected to be. She makes her sons into miniature husband-figures from their earliest childhood. Thus, when Paul gets older and begins to have important relationships with girls, his attachment to her prevents him from loving them as fully as he feel he should.

Paul has grown up physically, but his mind is still immature. He is unable to love Miriam as she is prepared to love him, “... this is because of his unresolved fixation upon his mother” (Lawrence, 1994, p. 98). And the dependence on his mother makes it easy for Paul to give up and seek for comfort from his mother when he meets some troubles. And when Mrs. Morel shoes her rejection to Miriam, he feels tortured and dares not admit his love.

As we know, Lawrence was roughly acquainted with Freud's theories, so it is not surprising that his characterization of Paul, in Sons and Lovers, should have been one of the first Freudian "case studies" (Gilbert, 1997, p. 73). The relationship between Paul and his mother grows frankly Oedipal as Mrs. Morel’s hostility to Mirianm becomes more and more irrepressible. It seems as though Paul is pouring all of the passion and devoteion which he might have had for Miriam into his care for his mothe. And his mother, for her part, honestly admits that Paul must take the place of the husband she feels she never "really" had.

Besides being a son, and a lover, Paul is also very importantly artist. Thus we see Paul being simulated and encouraged both by his mother and Miriam. His mother "urges" him toward success for her sake—so that she can live through him, while Miriam eagerly, flattering, encourages his talent for his own sake because she is self-sacrificingly in love with his genius and quickness. Yet whatever the respective motivations of the two women, it is clear from Paul's character and from his relationships with them that without their help he might not achieve the artistic success that we feel he destined to achieve.

Mrs. Morel partially created yet partially destroyed Paul's talents and hopes. Even when Mrs. Morel seems to love Paul most, we sense that she is somehow corrupting him with her unusual love.

\section{Love Between Paul and Miriam}

Miriam is a beautiful girl with black curls "fine and free" and the attraction of "a shy, wild, quiveringly sensitive thing” (Gilbert, 1997, p. 75), who loves poetry and resents being kept at home to do housework, While Paul is a young literature and art lover. Their similarities lay the foundation of their love. Paul is flattered and fascinated by her mind, and by her interest in his mind, for as Mrs. Morel's observes, Miriam seems to want to "absorb" all of him in her almost fanatic enthusiasm from his genius. Mirian's intensity reveals itself 
not only in this, however, but also in her physical fear and awkwardness, a sense of strain and stiffness in the way she stands and walks. Later, when she and Paul grow up more and are confronted with issue of sex, Miriam's religious and "spiritual” proclivities prevent her from being able to relax sexually. She is always frigid, rigidly against Paul. It is finally this stiffness, this "woodenness", this inability to relax and give herself to ordinary life, physical, and social, that turns Paul against Miriam, for though he is plainly under his mother's influence in breaking off the relationship, it is rather clear, too, that Paul could never find any kind of ultimate happiness in a marriage to someone as purely spiritual as Miriam. Though Miriam has become increasingly important in Paul's life, Mrs. Morel is still her son's chief confidante, counselor, and his first and greatest love.

Finally, he even writes a rather cruel letter to Miriam:

You see, I can give you a spirit love, I have given it you this long, long time; but not embodied passion. See, you are a nun. I have given you what I would give a holy nun-as mystic monk to a mystic nun. Surely you esteem it best. (Lawrence, 1994, p. 156)

Paul has come back to his mother. Hers is the strongest tie in his life. It is the one place in the world that stands solid and does not "melt onto unreality".

\section{Love Between Paul and Clara}

Compared with the former two love affairs, Paul and Clara's love seems to be the craziest, yet the most short-lived. Clara Dawes is characterized as a maturely sexual, ripely responsive woman, an opposite of Miriam. She comes to replace Miriam and satisfy Paul for what Miriam, the reserved girl, could not offer. Things are imbued with sex when Paul is with Clara. Sex is the foundation of their love; which evokes their passion. It is with Clara that Paul feels the greatness of the cosmos and finds his self as a man of nature, who exists in the most primitive way and satisfies his desire.

Besides the sexuality, what lights their passion is Clara's courage. Clara is depicted as a new 20th-century woman who advocates women's rights. Determined to be independent, she leaves her husband, earns her own living, and has an extramarital affair with Paul, which requires courage in her time. Clara can be viewed as a representative of the many post-Victorian women who rebelled against the traditional image of woman as the "weaker sex".

After Paul and Clara have experienced the carnal sexuality, they begin to ask for more about the spiritual communication. However, neither of them is satisfied. Paul attaches great importance to cultural life. He loves literature and art, which ties Miriam and him closely in the spiritual world. But Clara cannot replace Miriam in the spiritual world. She is not a romantic girl like Miriam: she will not be so fond of talking about literature; she will not stimulate Paul's work as an artist. They do not have any bond in the spiritual communication. Paul ever tells his mother, "Sometimes, when I see her just as the woman, I love her, mother; but then, when she talks and criticizes, I often don't listen to her” (Lawrence, 1994, p. 350).

Sexual life without spiritual support cannot last for long. They soon feel their passion exhausted. Finally Clara goes back to her husband. 


\section{Conclusions}

The novel tells the fruitless love between three pairs of lovers: Paul and Mrs. Morel, Paul and Miriam, and Paul and Clara, with the foundation of their loves laid on some necessary factors but not on all factors. The failure of their loves is caused by lack of some factors.

Paul's relationship with his mother is a perversion of a woman's natural love for her child, but as Paul is growing older, especially when he fell in love with Miriam, the mother's grows frankly Oedipal. Although we are warm to the mother's intelligence, her wit, her brave struggle against poverty, and her passionately devoted to her sons, we often feel that there is something sinister about Paul's mother. We sense that she is somehow corrupting him with her love.

Paul and Miriam are spiritual lovers. They have several bonds of love such as love of literature and art. But because of Miriam's defects, they cannot feel the joy of sexual love since they sense no passion, and Paul feels he was bound. Thus they have to part with each other. Paul's relationship with Miriam collapsed because it was spiritual and immature.

Paul and Clara only have the carnal sexuality. But they cannot communicate with each other. Paul keeps his fixation on Miriam in the spiritual word and Clara feels he did not belong to her. Their sexual love becomes tiring and boring for lack of spiritual communication. Paul's relationship with Clara collapsed because it has become all physical. Though his body adores Clara, Paul's mind is not very fully attuned to hers. His intense attachment to his mother keeps him from properly loving any other woman.

Sons and Lovers concludes with Paul's walking "quickly" - a significant pun - towards the town before him, the town which is "faintly humming" and "glowing" with its own mysterious and various life. He is mature at last; he has passed through the final crisis in his growth. He has faced death and separation from his mother and having overcome these he is ready at last to try his single strength against the world.

\section{References}

Buenaflor, J. L. (1998). Ursula Brangwen: The lady of the dance. Kutatown: University of Pennsylvania.

Gilbert, S. (1997). D. H. Lawrence's Sons and Lovers and other works. Beijing: Foreign Language Teaching and Research Press. GUI, Y. Q. (1985). Selected reading in English and American literature. Beijing: Translation Company Press.

Gutierrez, D. (1980). D. H. Lawrence and modern destructiveness. Suicide and Life-Threatening Behavior, 10(4), 219.

Lawrence, D. H. (1994). Sons and lovers. Beijing: Foreign Language Teaching and Research Press.

LIU, B. S. (2001). A short history of English literature. Zhengshou: Henan People’s Publishing House.

Schneider, J. D. (1986). The consciousness of D. H. Lawrence: An intellectual biography. Lawrence: University Press of Kansas. WANG, L. Y. (1996). Image of D. H. Lawrence’s novel. Foreign Literature Review, 4, 62-68.

YANG, L. M. ( 1988). Teachers' book of college English. Beijing: Foreign Language Teaching and Research Press.

YANG. L., \& WANG, C. C. (2011). Oedipus complex in literature works. Journal of Language Teaching and Research, 2(6), $1420-1424$. 